DOI: 10.14526/2070-4798-2020-15-1-115-119

\title{
The effectiveness study of park volleyball use during extracurricular activity of senior pupils
}

\author{
Aleksandr V. Dorontsev ${ }^{*}$, Natalya V. Ermolina ${ }^{2}$, Elena B. Mayorova ${ }^{2}$, Yuliya A. Lyamina ${ }^{2}$ \\ ${ }^{1}$ Astrakhan State Medical University \\ Astrakhan, Russia \\ ORCID: oooo-ooo1-9446-103X, aleksandr.doroncev@rambler.ru* \\ ${ }^{2}$ Astrakhan State University \\ Astrakhan, Russia \\ ORCID: ORCID: OOOO-OOO1-9228-748X tomara-72_64@mail.ru \\ ORCID: oooo-0oo2-2049-6539, maiorovaeb@mail.ru \\ ORCID: 000o-0002-2052-0674, Lyamina.76w@mail.ru
}

\begin{abstract}
Nowadays scientists pay more attention to modified kinds of sport, such as park volleyball, beach volleyball, football and handball, street-ball, foot-volleyball, show-ball and other games. They are characterized by the dynamic actions. For additional lessons in these kinds of sport we can use open sports grounds, park and beach zones. In order to define the effectiveness we studied the results of park volleyball use in terms of sectional lessons among senior pupils of municipal budgetary educational establishment "Gymnasium 3" in Astrakhan. Materials. Theoretical analysis and results summarizing of scientific methodical works and materials, which correspond with this work. The results of physical fitness control tests, medical check-up results, the results of the functional tests, initial information collection in a form of a questionnaire survey. Research methods. Information sources analysis and summarizing, pedagogical experiment. Statistical significance of the received results differences from the control group and the experimental group was estimated using Student $t$-test. Correlation analysis was fulfilled using Pearson correlation coefficient. Results. We tested the methodology of additional park volleyball lessons. We registered valid increase of physical qualities and functional indices level. Conclusion. Park volleyball use as additional lessons helped to realize productive use of free time, increase the level of physical readiness and pupils' communicative abilities.
\end{abstract}

Keywords: senior pupils, park volleyball, additional lessons.

For citation: Aleksandr V. Dorontsev*, Natalya V. Ermolina, Elena B. Mayorova, Yuliya A. Lyamina. The effectiveness study of park volleyball use during extracurricular activity of senior pupils. Russian Journal of Physical Education and Sport. 2020; 15(1): 94-97. DOI: 10.14526/2070-4798-2020-15-1-115-119

\section{INTRODUCTION}

Studying the tendencies of physical culture and sport development in modern society and these tendencies reflection in physical upbringing programs for educational establishments shows that some changes should happen in the content of additional physical culture and sport lessons [1,11]. Extracurricular activity in terms of Federal State Educational Standards (FSES) introduction becomes urgent, as standards underline that extracurricular activity should be used obligatory. It is the resource, which helps a school to achieve new quality of education [3]. In a new Federal state educational standard of the initial secondary education special attention is paid to extracurricular activity among schoolchildren [4]. Modern process of physical upbringing among schoolchildren is mainly directed toward high level of physical readiness achievement. It is defined by the corresponding state educational standards and physical upbringing programs [9]. At the same time senior pupils don't have the skills of self-organization, motivation and interest in physical culture lessons during their free time [10]. Specialists in the sphere of physical upbringing in Russia and abroad search for new ideas and approaches to physical upbringing among youth $[13,14,15,16]$.The main thing in this problem solution is upbringing motivation of young people to go in for systematic physical culture and sports lessons not only under the direction of the coaches teachers, but also independently [2]. An important factor of independent lessons organization among the pupils is physical load correspondence with the level of readiness [8]. Not adequate physical 
load together with tense emotional atmosphere in some cases can lead to pathological changes development in different system of an organism $[5,6,7]$. That is why we studied the characteristics of park volleyball lessons organization in terms of extracurricular activity at a secondary school. The aim of the research: to define the effectiveness of park volleyball use during free time among senior pupils. The objective: to substantiate experimentally the methodology of park volleyball use in the practice of sectional work.

\section{MATERIALS AND METHODS}

The students of the $10^{\text {th }}$ grades from Gymnasium 3 (Astrakhan) took part in the experiment ( 36 people- 22 boys and 14 girls). Two groups were formed: the experimental group $-\mathrm{n} 1=$ 15 people ( 9 boys and 6 girls), who went in for park volleyball and the control group $\mathrm{n} 2=21$ people (13 boys and 8 girls), who had physical culture lessons in terms of secondary school educational program.

During the work we used complex physical culture programs, created in accordance with state educational standard of secondary education and methodical manuals of additional pedagogical education. For the system analysis of the set objective we used the research works of the leading specialists on the basis of publications in scientific journals, indexed in scientific bases RINTS (Russian Index of Scientific Citation), Scopus, WoS. The held questionnaire survey helped to define motivational attitude and level of interest among senior pupils in physical culture lessons, helped to reveal the priorities according to the kinds of sport. The research was held on the basis of two-stage pedagogical experiment. On the first stage we estimated the level of physical and functional readiness among all respondents and formed the groups for additional park volleyball lessons without taking into account gender differences. During the second stage realization we estimated the effectiveness of created by us park volleyball methodology. We defined the degree of the lessons influence effectiveness on the level of physical qualities development. We held a comparative analysis of physical readiness in the control and experimental groups. The research results were handled with the help of standard statistical packages of Statistica 11 programs. Critical level of validity of null statistical hypothesis $\mathrm{p}$ was equal to 0,05 . The research works were held at sports bases of "Gymnasium 3" in Astrakhan, of Astrakhan State Medical University and Astrakhan State University in 2018/19 (Russia).

\section{RESULTS AND DISCUSSION}

The main peculiarity of the experimental methodology for the experimental group $(\mathrm{n} 1=$ 15) was variable orientation of conditions for the pupils participation in park volleyball lessons. We mainly used game and competitive methods in the methodology in order to create and support active interest in lessons. Density of the lessons was planned in accordance with the functional and technical level of pupils' readiness. The experimental methodology of park volleyball lessons included three-component structure of the main part. It had the alternation of stretching, generally developing, power oriented and playing volleyball exercises. They were are necessary for a complex physical and technicaltactical readiness. The main criterion of the results estimation in tournaments was not the victory or the taken place, but the amount of the held games by the definite respondent and the percentage of the victories. The content of the team was not limited according to gender and the teams, as a rule, had mixed content.

The density of lessons was defined by the playing regimen. It was characterized by intensity increase in terms of pupils' technical level increase. Typical to volleyball high emotional atmosphere influenced greatly hemodynamic indices. Heart rate (HR) during the game was $125 \pm 9,2$ beats/min at the beginning of the research and $153 \pm 8,8$ beats/min during the last month of the observations. It should be noted that early HR renewal during passive rest after the game (10 $\mathrm{min}$ ) was $97 \pm 7,3$ beats $/ \mathrm{min}$ at the beginning of the experiment and $91 \pm 8,3$ beats/ min at the end of the experiment. Arterial and pulse pressure indices didn't change much.

During physical readiness level estimation in the experimental group $\left(\mathrm{n}_{1=}, 15\right)$ we revealed that the most distinct dynamics was in speed-power oriented indices: 30 meters running boys at the beginning of the academic year $-5,92 \pm 0,53$ s., at the 
end of the year $-5,10 \pm 0,47$ s. $(p<0,041 ; r=0,433)$, girls at the beginning of the research $-6,41 \pm 0,59$ $\mathrm{s}$, at the end of the experiment $-5,73 \pm 0,31 \mathrm{~s}(\mathrm{p}$ $<0,041 ; \mathrm{r}=0,433)$. 100 meters running, the initial result $-15,73 \pm 1,01 \mathrm{~s}$, the final result $-14,27 \pm 0,67 \mathrm{~s}$ ( $\mathrm{p}<0,037$; $\mathrm{r}=0,513$ ); girls at the beginning of the academic year $-18.39 \pm 1,33 \mathrm{~s}$, at the end $17.12 \pm 0,45 \mathrm{~s}$, ( $<<0,037 ; \mathrm{r}=0,513$ ). Standing longjump: boys at the beginning of the research showed the average result $191 \pm 12,3 \mathrm{~cm}$, at the end of the research $-205 \pm 11,3 \mathrm{~cm}(\mathrm{p}<0,043 ; \mathrm{r}=0,571)$, among girls the indices at the initial protocol were $168 \pm 11,2 \mathrm{~cm}$, at the end of the research $-183 \pm 10.0$ cm ( $<<0,044 ; r=0,527)$. Shuttle run 4x9 m: the initial testing in boys $-11,35 \pm 1,23 \mathrm{~s}$, in the final protocol - 10,00 $\pm 0,87 \mathrm{~s}$, ( $<<0,045 ; \mathrm{r}=0,497)$, in girls at the beginning of the research $-11,73 \pm 1,22$ $\mathrm{s}$, at the end of the experiment $-10,5 \pm 0,57 \mathrm{~s}(\mathrm{p}<$ o,047; $\mathrm{r}=0,479$ ).

During comparison of physical qualities indices development in two groups $\left(\mathrm{n}_{1=} 15\right)$ and $\left(\mathrm{n}_{2}\right.$ $=21$ ) the differences between the average value of speed-power oriented indices and coordination in the experimental group were defined as statistically valid ( $\mathrm{p}<\mathrm{0}, 005)$. During endurance, power oriented and directly power indices estimation considerable intergroup differences were not defined.

\section{CONCLUSION}

Thus, the received results prove valid effectiveness of park volleyball use as one of the kinds of sport for sectional lessons. Flexible methodology of teams formation, simplified rules of competitions, the availability of the lessons organization places help to form sports-health improving orientation of park volleyball, directed to independent organization and the conditions creation for social activity of pupils.

Using game and competitive methods of lessons organization gave an opportunity to plan the intensity and the volume of physical load in terms of difficult playing elements technique mastery improvement.

At the same time, most respondents had not high level of physical and functional readiness that is why special attention should be paid to the adequate character of physical load, especially during the initial period of going in for park volleyball.

\section{References}

1. Gavrishova E. V., Grachev A.S., Tretyakov A.A. Using informative-communicative technologies in additional health-improving activity organization among students taking into account the type of motivation. Teoriya I praktika fizicheskoj kul'tury = Theory and practice of physical culture. 2020; 1: 44-47 [In Russ., In Engl.].

2. Dorontsev A. V., Gorst V.R., Medvedeva A.S. Risk factors determination of neurological pathologies development in structural elements of vertebral column among athletes, who go in for power oriented kinds of sport. Uchenye zapiski universiteta imeni P.F. Lesgaft. 2017; 8 (150):25-29 [In Russ.].

3. Ermolina N. V., Morozova O.V., Dorontsev A.V.,Lyamina Yu.A. Schoolchildren's physical readiness analysis according to the results of "President competitions" during 2015-2016 and 2016-2017 academic years. European Social Science Journal. 2018; 2-1: 152-161 [In Engl.].

4. Markov R. A., Almaev K.R. Health state of military and pre-military age boys in Russia. Astrahanskij Medicinskij Zhurnal. 2016; 11(3) [In Russ.].

5. Chichkova M.A., Svetlichkina A.A. Patent 2672934 RF. The way of complex estimation of cardiovascular system indices among disabled people. URL: https://yandex.ru/patents/doc/ RU2672934C1_20181121.

6. Chichkova M.A., Svetlichkina A.A. Patent 2652968 RF. The way of complex estimation of cardiovascular system indices among athletes. URL: https://yandex.ru/patents/doc/ RU2652968C1_20180503.

7. Chichkova M.A., Svetlichkina A.A. Patent 2672935 RF. The way of complex estimation of cardiovascular system indices among people with auditory problems. URL: https://yandex.ru/ patents/doc/RU2672935C1_2017132798.

8. Svetlichkina A.A., Chichkova M.A. Cardiovascular system activity estimation among people with restricted auditory abilities. Kardioologiya I kardiohirurgiya: innovacionnye resheniya - 2016: sbornik materialov yubilejnoj 10-j mezhregional'noj nauchno-prakticheskoj konferencii [Cardiology and cardio-surgery: innovative solutions - 2016: collection of materials of the $10^{\text {th }}$ anniversary Interregional scientificpractical conference]. State Budgetary Educational Establishment of Higher Education "Astrakhan State Medical University”. 2016: 176-178 [In Russ.]. 9. Smirnova U. V., Kareva Yu.Yu., Nikolaeva I.V., Shikhovtsov Yu.V., Shikhovtsova L.G. The peculiarities of the basic physical qualities demonstration among athletes in volleyball. Uchenye zapiski universiteta imeni P.F. Lesgaft. 
2019; 4(170): 309-313 [In Russ.].

10. Shikhovtsov Yu.V., Nikolaeva I.V., Kudinova Yu.V., Shikhovtsova L.G. Technical devices for defensive actions study in volleyball. Uchenye zapiski universiteta imeni P.F. Lesgaft. 2016; 1(131): 281-287 [In Russ.].

11. Shikhovtsov Yu.V., Nikolaeva I.V., Nokolaev P.P. Volleyball is a universal means of health improvement among students. Bezopasnost' zhiznedeyatel'nosti I zdorov'yasberezheniya na sovremennom etape: perspektivy razvitiya: materialy Vserossijskoj nauchno-prakticheskoj konferencii [Life safety and health protection at a modern stage: perspectives of development: materials of All-Russian scientific-practical conference]. Samara. 2012: 154-155 [In Russ.].

12. Chichkova M. A., Svetlichkina A.A., Dorontsev A.V. Physical loads individual planning among swimmers-beginners taking into account EGC indices. Uchenye zapiski universiteta imeni P.F. Lesgaft. 2017; 7(149): 203-207 [In Russ.].

13. V.Yu. Karpov, S.Yu. Zavalishina, A.V.
Dorontsev, K.K. Skorosov, D.A. Ivanov Physiological basis of physical rehabilitation of athletes after ankle injuries. Indian Journal of Public Health Research and Development. 2019; 10(10): 2723-2728.

14. Sandercock, G.R.H., Ogunleye A., Voss C. Screen Time and Physical Activity in Youth: Thief of Time or Lifestyle Choice. Journal of Physical Activity and Health. 2013; 9(7): 977-984.

15. Silva P. Physical Activity in High School During 'Free-Time' Periods. European Physical Education Review. 2014; 21(2): 135-148.

16. Marina A. Chichkova, Anastasiya A. Svetlichkina, Alexsandr V. Dorontsev. Comparative characteristic of cardiovascular system stateamong people going in for competitive and health-improving bodybuilding. Pedagogikopsihologicheskie I mediko-biologicheskie problemy fizicheskoj kul'tury I sporta = The Russian journal of Physical Education and Sport. 2018; 13(1): 198205. DOI 10/14526/01_2018_301 [In Russ., In Engl.].

Submitted: 15.02.2020

Author's information:

Aleksandr V. Dorontsev - Candidate of Pedagogics, Associate Professor, Astrakhan State Medical University, 41400o, Russia, Astrakhan, Bakinstakya str., House 121, e-mail: aleksandr.doroncev@ rambler.ru

Natalya V. Ermolina - Candidate of Pedagogics, Associate Professor, Astrakhan State University, 414056, Russia, Astrakhan, Tatuchsheva str., House 20a, e-mail: tomara-7264@mail.ru

Elena B. Mayorova - Senior Lecturer, Astrakhan State University, 414056, Russia, Astrakhan, Tatuchsheva str., House 20a, e-mail: maiorovaeb@mail.ru

Yuliya A. Lyamina - Senior Lecturer, Astrakhan State University, 414056, Russia, Astrakhan, Tatuchsheva str., House 20a, e-mail: Lyamina.76w@mail.ru 